\title{
Low diversity in the major histocompatibility complex class II DRB1 gene of the Spanish ibex, Capra pyrenaica
}

\author{
M Amills ${ }^{1}$, N Jiménez ${ }^{1}$, J Jordana ${ }^{1}$, A Riccardi ${ }^{1}$, A Fernández-Arias ${ }^{2}$, J Guiral ${ }^{2}$, JL Bouzat ${ }^{3}$, \\ $\mathrm{J} \mathrm{Folch}^{2}$ and $\mathrm{A}$ Sànchez ${ }^{1}$ \\ ${ }^{1}$ Departament de Ciència Animal i dels Aliments, Facultat de Veterinària, Universitat Autònoma de Barcelona, Bellaterra 08193, Spain; \\ 'Unidad de Tecnología en Producción Animal, Servicio de Investigación Agroalimentaria, Diputación General de Aragón, Apdo. 727, \\ Zaragoza 50080, Spain; ${ }^{3}$ Department of Biological Sciences, Bowling Green State University, Bowling Green, OH 43403, USA
}

\begin{abstract}
During the last two centuries, the Spanish ibex (Capra pyrenaica) has shown a significant demographic decline as a result of the progressive destruction of its natural habitat, disease epidemics, and uncontrolled hunting. Partial sequencing of the class II MHC DRB1 gene revealed that the Spanish ibex has remarkably low levels of genetic variation at this locus, with only six different $D R B 1$ alleles and an observed heterozygosity of $0.429-0.579$. The rates of nonsynonymous vs synonymous substitutions were significantly different in the peptide-binding region $\left(d_{N} / d_{S}=5.347, P=0.002\right)$, a feature that indicates that the DRB1 gene is under positive selection. A phylogenetic analysis of the Spanish ibex and a set of domestic goat $D R B 1$ alleles revealed that the reported sequences represent four major allelic lineages. The limited allelic repertoire of the $D R B 1$ gene in the Spanish ibex is likely
\end{abstract}

the direct result of the recent history of population bottlenecks and marked demographic decline of this species. A genetic survey of 13 microsatellite loci was consistent with this idea. The Spanish ibex subspecies C. p. hispanica and C. p. victoriae consistently showed considerably lower levels of microsatellite heterozygosity $\left(H_{\mathrm{o}}=0.184-0.231\right)$ and allelic diversity (mean number of alleles per locus $=2-2.4$ ) than those reported in other wild ruminants. This study demonstrates the significance of both natural selection and the demographic history of populations in determining patterns of genetic variation at MHC loci. In addition, our results emphasize the importance of locally adapted populations for the preservation of genetic diversity.

Heredity (2004) 93, 266-272. doi:10.1038/sj.hdy.6800499

Published online 23 June 2004

Keywords: genetic diversity; adaptive variation; MHC; heterozygosity; microsatellite

\section{Introduction}

The major histocompatibility complex (MHC) plays an important role in the adaptive immune response of vertebrates (Trowsdale, 1993). Class II DRA and DRB genes of the MHC encode heterodimeric glycoproteins formed by $\alpha$ and $\beta$ chains that bind and present both self and foreign peptides to helper $\mathrm{T}$ cells, playing a major role in T-cell recognition. The amino-acid positions of the DR- $\beta$ chain, which form the peptide-binding region (PBR), have been shown to be highly polymorphic in most vertebrate species. Genetic diversity at this locus is believed to be maintained by balancing selection favouring antigen-presenting cells to bind a wide array of self and non-self-peptides, thus conferring higher resistance to infectious diseases ( $\mathrm{O}^{\prime}$ Brien and Evermann, 1988; Hughes et al, 1994; Hedrick and Kim, 2000).

Previous studies have shown that the demographic history of populations may affect the genetic diversity present at the MHC (Yuhki and O'Brien, 1990; Hughes

Correspondence: $M$ Amills, Departament de Ciència Animal $i$ dels Aliments, Facultat de Veterinària, Universitat Autònoma de Barcelona, Bellaterra 08193, Spain. E-mail: Marcel.Amills@uab.es

Received 29 October 2003; accepted 19 February 2004; published online 23 June 2004 and Yeager, 1998). For example, population bottlenecks and genetic drift have been shown to play a major role in shaping MHC diversity of many wild species (Mikko et al, 1999). Natural populations of muskox (Ovibos moschatus), moose (Alces alces), fallow deer (Dama dama), beaver (Castor fiber), Asiatic lion (Panthera leo persica), cotton-top tamarin (Saguinus oedipus) and the cheetah (Acinonyx jubatus), among others, have shown reduced allelic variation or even monomorphism at the MHC loci, indicating that the presence of high genetic diversity is not a universal feature of this genetic system $\left(\mathrm{O}^{\prime}\right.$ Brien et al, 1987; Yuhki and O'Brien, 1990; Watkins et al, 1991; Ellegren et al, 1993, Mikko et al, 1999). Studying closely related species with different demographic histories (eg, endangered species that have suffered drastic reductions in population size $v s$ populations that have not gone through genetic bottlenecks) may provide insights into the relative importance of selective and stochastic processes shaping the genetic diversity present at the MHC.

We have undertaken a population genetic analysis of the MHC DRB1 gene in the Spanish ibex (Capra pyrenaica), a wild goat species distributed throughout the South-Eastern mountains and the Gredos and Batuecas mountain ranges of Spain (Pérez et al, 2002). Four different subspecies of Spanish ibex (SI), C. p. hispanica 
$(\mathrm{CPH})$, C. p. victoriae (CPV), C. p. pyrenaica (CPP) and C. p. lusitanica (CPL), were originally characterized on the basis of horn morphology, coat colour and other phenotypic features (Cabrera, 1911). At present, only $\mathrm{CPH}$ and $\mathrm{CPV}$ persist having an allopatric distribution in the Iberian Peninsula (Pérez et al, 2002). In contrast, CPL became extinct in the 19th century and the last specimen of CPP died in January 2000 (Pérez et al, 2002). Disease epidemics, uncontrolled hunting, overgrazing, and progressive destruction of natural habitats likely played an important role in the marked demographic decline of the SI. Although current estimated population sizes of SI are fairly large in certain areas, for example, 14000 individuals in the Sierra Nevada population, the occurrence of severe demographic bottlenecks during the 19th and 20th centuries, with effective sizes ranging from 5 to 100 individuals, is well documented (Crampe, 1991; Manceau, 1997; Pérez et al, 2002).

The occurrence of recent historical population bottlenecks, increased isolation, and the drastic reduction in the SI distribution range may have had profound effects on the genetic diversity of this species. The study of MHC variation in representatives of three subspecies of the SI provides an appropriate case study for evaluating the potential effects of demographic changes on the genetic variability of the MHC. In this study, we performed PCR-RFLP and DNA sequence analyses to evaluate levels of genetic variation at the MHC class II $D R B 1$ gene. In addition, the genetic analysis of 13 microsatellite loci provided an independent line of evidence for assessing overall levels of genetic diversity in the SI. Results from this study are discussed in light of the evolutionary processes that may have led to the observed patterns of MHC variation in the SI.

\section{Materials and methods}

\section{Sample sources}

Blood and tissue (liver or muscle) samples from 43 SI were used as a source of genomic DNA. Samples from SI were collected from five populations located throughout a wide range of its geographic distribution (Figure 1). These included 23 individuals of subspecies C. $p$. victoriae (CPV), 19 individuals of C. p. hispanica (CPH), and the last representative of C. p. pyrenaica (CPP).

\section{PCR-RFLP typing and DNA sequencing of the MHC $D R B 1$ gene}

Protocols for genomic DNA isolation from blood samples are described elsewhere (Amills et al, 1996a). The purification of genomic DNA from liver samples was performed by digesting $300 \mathrm{mg}$ of tissue in $500 \mu \mathrm{l}$ lysis buffer (50 mM Tris-HCl, pH 8; 20 mM EDTA, pH 8; 2\% SDS; $1 \mathrm{mg} / \mathrm{ml}$ Proteinase K) overnight at $37^{\circ} \mathrm{C}$. Genomic DNA was then purified through a standard phenolchloroform extraction followed by an ethanol precipitation (Sambrook et al, 1989). DNA samples were re-suspended in $48 \mu \mathrm{l}$ of sterile water and $2 \mu \mathrm{l}$ of RNAase $(10 \mathrm{mg} / \mathrm{ml})$ for further PCR analyses.

The second exon of the DRB1 gene was typed by using both PCR-RFLP and direct sequencing of the PCR product. Exon 2 was amplified as previously described (Amills et al, 1996a) and PCR products were digested at $37^{\circ} \mathrm{C}$ for $12 \mathrm{~h}$ with $5 \mathrm{U}$ of $R s a \mathrm{I}$ restriction endonuclease

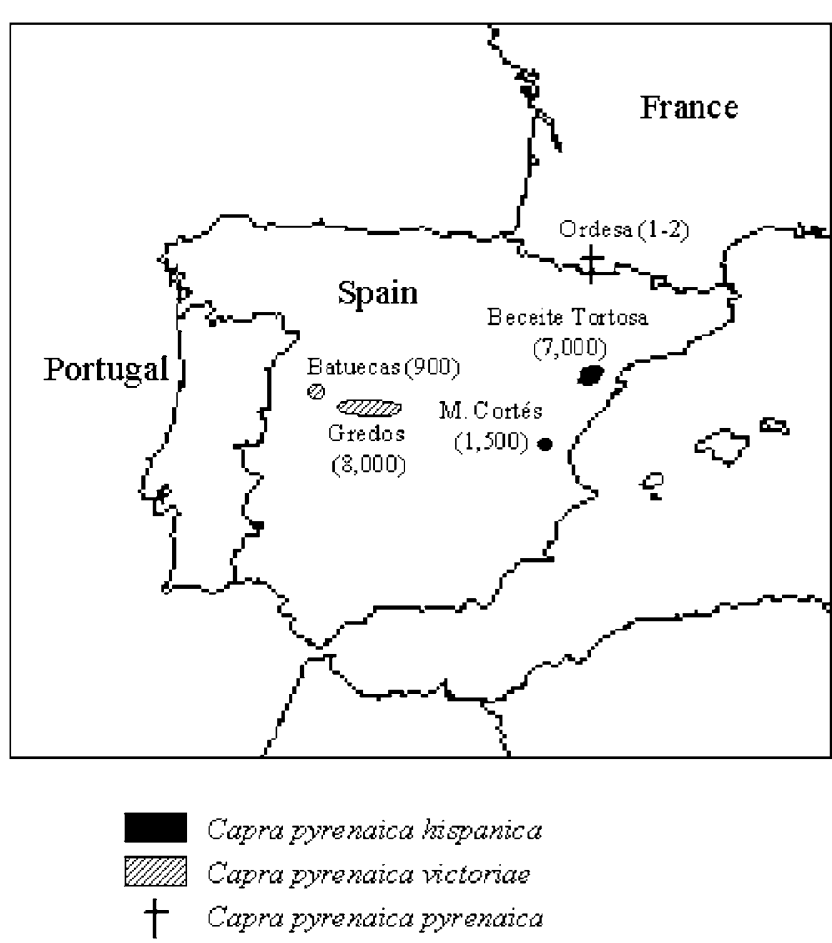

Figure 1 Range of geographic distribution of the five Spanish ibex (Capra pyrenaica) populations sampled in this study (Ordesa, BeceiteTortosa, Muela de Cortés, Gredos and Batuecas). Numbers in parentheses indicate population sizes reported by Pérez et al (2002) and corresponding to estimates obtained in 1993-1997. The Ordesa National Park C. p. pyrenaica population had 1-2 individuals in 1997 but the last representative of this subspecies died in January 2000.

(Roche Diagnostics SL, Barcelona 08006, Spain). This enzyme has been previously shown to yield at least 15 different RFLP patterns in domestic goats (Amills et al, 1996a). Restriction fragments were electrophoresed in 3\% high-resolution agarose gels allowing us to identify homozygous and heterozygous genotypes (Amills et al, 1996a). All distinct DRB1.1 to DRB1.5 PCR-RFLPcharacterized alleles present in the SI were cloned and sequenced (GenBank accession numbers AF461692AF46196). Amplified DRB1 products were cloned using the pCR 2.1-TOPO vector (Invitrogen BV, $9704 \mathrm{CH}$ Groningen, The Netherlands) following the manufacturer instructions. Each DNA clone reported in this study was sequenced forward and reverse in an ABI Prism 377 DNA sequencer (Perkin Elmer Biosystems, Foster City, CA 94404, USA) using the ABI PRISM ${ }^{\mathrm{TM}}$ Cycle Sequencing Kit (Perkin Elmer Biosystems, Foster City, CA 94404, USA). At least two independent clones were sequenced for Capy-DRB1.1, -DRB1.2, -DRB1.3 and -DRB1.5, whereas a single clone was sequenced for CapyDRB1.4. The sequence of the Capy-DRB1.6 allele (Genbank accession number AY351788) was inferred from the alignment of amplified exon 2 sequences from different individuals harbouring this particular allele.

Since PCR-RFLP may underestimate the levels of genetic variation, we direct-sequenced exon 2 from each one of the individuals that had been previously typed by this method. Visual inspection of these sequences showed that each one of the RFLP patterns represented a single allele sequence. 
Microsatellite typing

A total of 13 microsatellites, previously described in other ruminant species, were selected to evaluate overall levels of genetic diversity in the SI. Microsatellite loci were selected on the basis of their polymorphism, PCR amplification feasibility, and available data for comparison with other goat species (Jiménez et al, 1999). These were: INRA005, INRA023, INRA032, INRA035, INRA037, INRA063, CHIAE54, CSSM66, HEL9, ILST005, ETH10, ETH152, ETH225. Primer identification, PCR conditions and amplification profiles for each microsatellite locus are described elsewhere (Brezinsky et al, 1993; Kaukinen and Varvio, 1993; Steffen et al, 1993; Toldo et al, 1993; Barendse et al, 1994; Vaiman et al, 1994; Amills et al, 1996b). Fluorescent genotyping was performed in an ABI Prism 310 automated DNA sequencing system (Perkin Elmer Biosystems, Foster City, CA 94404, USA).

Phylogenetic analysis of the Capy-DRB1 sequences and calculation of the number of synonymous vs nonsynonymous substitutions

The DNA sequences of the SI DRB1 alleles were aligned using the Clustal-X multiple sequence alignment program (Thompson et al, 1997). The MEGA 2.1 program (Kumar et al,1993) was used to estimate relative rates of nonsynonymous $\left(d_{\mathrm{N}}\right)$ and synonymous substitutions $\left(d_{\mathrm{S}}\right)$ according to Nei and Gojobori (1986), using Jukes and Cantor's (1969) correction for multiple hits. To test whether positive selection was operating at this locus we compared the relative abundance of synonymous and nonsynonymous substitutions using a Z-test (Nei and Kumar, 2000). The variance of $d_{\mathrm{N}}$ and $d_{\mathrm{S}}$ was estimated using the bootstrap method implemented in MEGA, with 500 replications (Schneider et al, 2000). To estimate substitution rates in the domestic goat (Capra hircus) we selected all DRB1 gene sequences currently deposited in GenBank and identified 47 alleles with distinct sequences at the amplified region (GenBank accession numbers: AF376809-813, AB008345-362, U00183-203, X83367, CAZ92717-725).

MEGA was also used to perform phylogenetic analyses of the SI DRB1 alleles reported in this study and a set of domestic goat DRB1 sequences (see Figure 2 for GenBank accession numbers). Two independent phylogenetic methods (neighbour-joining and maximum parsimony) were used to confirm the reliability of the observed phylogenetic patterns. The neighbour-joining tree was constructed using Jukes and Cantor (1969) genetic distances. Bootstrap resamplings of 1000 multiple data sets provided estimates of relative confidence for nodes in our phylogenetic trees.

\section{Population data analyses}

Both DRB1 and microsatellite allele and genotype frequencies were estimated by direct counting, and observed $\left(H_{\mathrm{o}}\right)$ and expected $\left(H_{\mathrm{e}}\right)$ heterozygosities and levels of genetic differentiation among populations $\left(F_{\mathrm{ST}}\right)$ were estimated using the BIOSYS-2 software (Swofford and Selander, 1999). Population structure was analysed by means of F-statistics using the variance based method described by Weir and Cockerham (1984) and implemented in the FSTAT computer program (Goudet, 2000). In order to test the significance of the different statistics for the null hypothesis of no differentiation at the

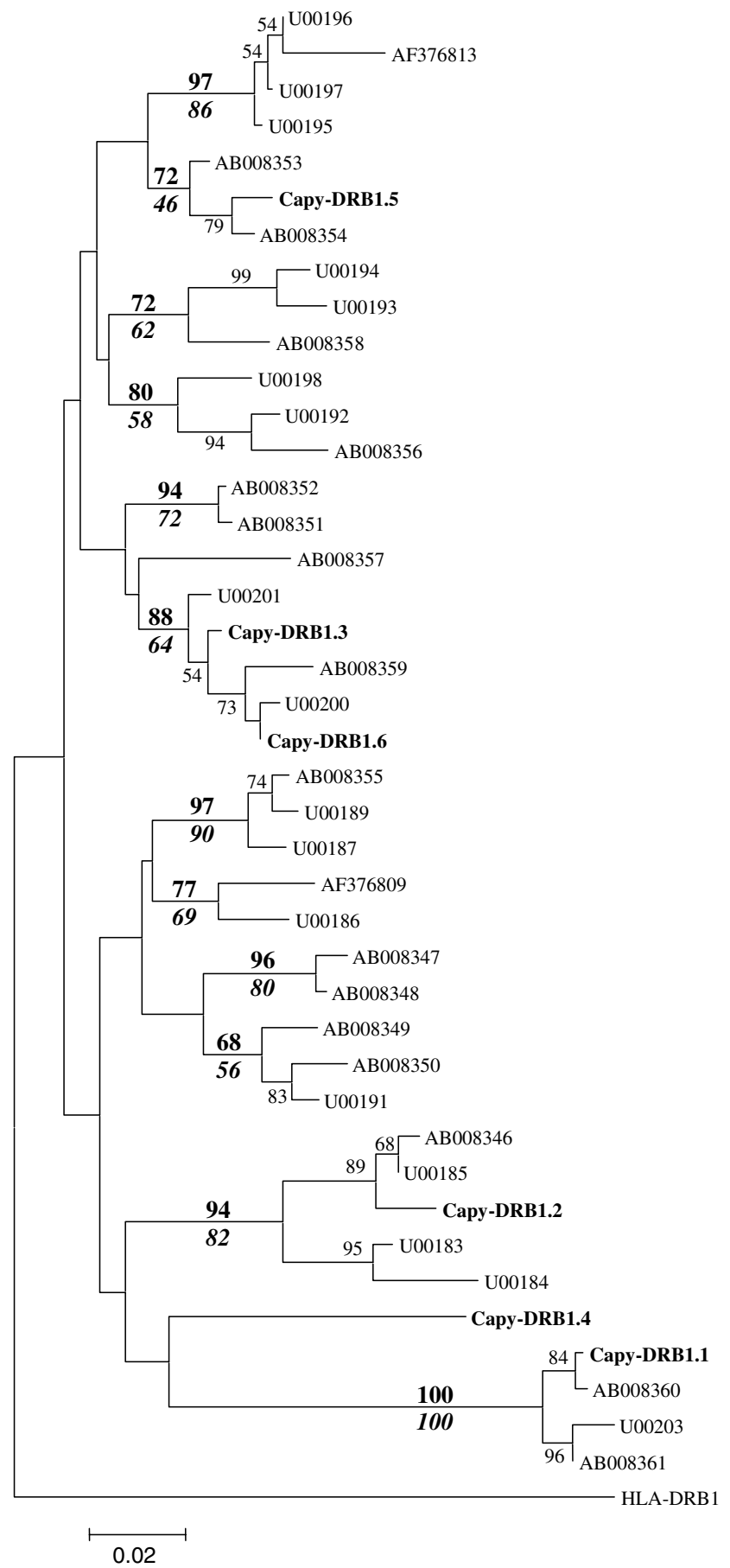

Figure 2 Neighbour-joining phylogenetic tree of the six Capy-DRB1 sequences from the Spanish ibex Capra pyrenaica (in bold) and selected sequences from the domestic goat (Capra hircus). Numbers in bold represent bootstrap values for 12 major DRB1 allelic lineages. Regular font and italics indicates bootstrap values from the neighbour-joining and maximum parsimony analyses, respectively. Domestic goat sequences are indicated by GenBank accession numbers. The human HLA-DRB1 sequence was used as an outgroup.

corresponding level, permutation and resampling tests (jacknifing and bootstrapping) were carried out as implemented in the programs mentioned above.

The $F_{\mathrm{ST}}$ values among pairs of populations were calculated using the GENEPOP program (Raymond 
and Rousset, 1995). In addition, GENEPOP was used to quantify the effects of migration on genetic structure and population subdivision. Gene flow was estimated between each pair of populations by converting $F_{\mathrm{ST}}$ to amount of gene flow $\left(N_{\mathrm{e}} \mathrm{m}\right)$, according to an island model under neutrality and negligible mutation (Slatkin, 1993). $N_{\mathrm{e}} \mathrm{m}$ indicates the average number of effective migrants per generation to produce the observed $F_{\mathrm{ST}}$ under the n-island model.

Phylogenetic trees among populations were produced by using the distance measure $D_{\mathrm{A}}$ (Nei et al, 1983). Takezaki and Nei (1996) suggested that the $D_{\mathrm{A}}$ distance is particularly suitable for constructing phylogenetic trees when the most critical issue is the topology of the tree rather than evolutionary time. Distance data were analysed with the neighbour-joining method of clustering (Saitou and Nei, 1987). The robustness of the dendrogram was evaluated by bootstrap resampling of loci (1000 replicates). All these calculations were carried out using DISPAN (Ota, 1993).

\section{Results}

\section{Genetic characterization of the MHC DRB1 gene in the Spanish ibex}

PCR-RFLP and sequence analyses of the Capy-DRB1 gene in three subspecies of the SI allowed us to detect six distinct alleles (Genbank accession numbers AF461692AF46196 and AY351788). One of these DRB1 alleles (Capy-DRB1.6) was found only in CPV whereas two other alleles (Capy-DRB1.4 and Capy-DRB1.5) were solely detected in the only representative individual of subspecies CPP. The observed heterozygosity $\left(H_{\mathrm{o}}\right)$ for the $D R B 1$ gene in the SI subspecies ranged from 0.429 (CPV) to $0.579(\mathrm{CPH})$ (Table 1).

We sequenced exon 2 of the DRB1 gene from five SI displaying the six RFLP-characterized alleles in this species. In total, $55(23.21 \%)$ of the 237 nucleotides sequenced were variable in the Capy-DRB1 gene. These resulted in $30(37.97 \%)$ variable amino-acid positions from a total of 79 amino acids. A total of 20 variable amino-acid positions were located at the peptide-binding region (PBR) of the DR $\beta$ molecule (Brown et al, 1993). The rate of nonsynonymous $\left(d_{\mathrm{N}}\right)$ and synonymous $\left(d_{\mathrm{S}}\right)$ substitutions for the PBR and non-PBR amino-acid

Table 1 Estimates of allelic diversity $\left(N_{a}\right.$, number of alleles per locus), and observed $\left(H_{\mathrm{o}}\right)$ and expected $\left(H_{\mathrm{e}}\right)$ heterozygosities for the Capy-DRB1 gene in C. p. hispanica (Muela de Cortés and BeceiteTortosa populations) and C. p. victoriae (Gredos and Batuecas populations)

\begin{tabular}{lrccc}
\hline Population & $\mathrm{N}$ & $\mathrm{N}_{a}$ & $\mathrm{H}_{o}$ & $\mathrm{H}_{e}$ \\
\hline C. $p$. hispanica & 19 & 3 & 0.579 & 0.562 \\
$\quad$ Muela de Cortés & 3 & 3 & 1.000 & 0.733 \\
Beceite-Tortosa & 16 & 2 & 0.500 & 0.516 \\
C. $p$. victoriae & 21 & 4 & 0.429 & 0.659 \\
$\quad$ Gredos & 12 & 4 & 0.500 & 0.707 \\
Batuecas & 9 & 4 & 0.333 & 0.575 \\
C. $p$. pyrenaica & 1 & 2 & 1.000 & 1.000 \\
\hline
\end{tabular}

$N$ indicates the number of sampled ibexes for each population and subspecies.
Table 2 Rates of nonsynonymous $\left(d_{\mathrm{N}}\right)$ and synonymous $\left(d_{\mathrm{S}}\right)$ substitutions for positions at the peptide-binding region (PBR), other regions not involved in antigen binding (No-PBR), and the complete sequence (All) of the DRB1 gene

\begin{tabular}{lcccc}
\hline & $d_{N}$ & $d_{S}$ & $d_{N} / d_{S}$ & $P$ \\
\hline Spanish ibex & & & & \\
PBR & $0.385(0.103)$ & $0.072(0.049)$ & 5.347 & 0.002 \\
No-PBR & $0.056(0.015)$ & $0.072(0.024)$ & 0.778 & 0.550 \\
All & $0.134(0.025)$ & $0.075(0.022)$ & 1.787 & 0.063 \\
& & & & \\
Domestic goat & & & & \\
PBR & $0.271(0.066)$ & $0.076(0.033)$ & 3.566 & 0.003 \\
No-PBR & $0.057(0.014)$ & $0.060(0.021)$ & 0.950 & 0.879 \\
All & $0.110(0.021)$ & $0.065(0.018)$ & 1.692 & 0.045 \\
\hline
\end{tabular}

Numbers in parentheses indicate standard deviations. The statistical significance of the test is shown as $P$.

positions, and the ratio of $d_{\mathrm{N}} / d_{\mathrm{S}}$ are shown on Table 2 . In the SI, the PBR region showed significantly higher rate of nonsynonymous $v s$ synonymous substitutions, with a ratio $d_{\mathrm{N}} / d_{\mathrm{S}}$ significantly larger than one $\left(d_{\mathrm{N}} / d_{\mathrm{S}}=5.347\right.$; $P=0.002)$. In contrast, the rates of nonsynonymous and synonymous substitutions at no-PBR sites were not significantly different $\left(d_{\mathrm{N}} / d_{\mathrm{S}}=0.778 ; P=0.550\right)$. The analysis of the DRB1 domestic goat sequences showed similar trends. The 47 DRB1 distinct sequences showed lower levels of amino-acid sequence divergence (18.4\%), with a positive and significant $d_{\mathrm{N}} / d_{\mathrm{S}}$ ratio at the PBR region $\left(d_{\mathrm{N}} / d_{\mathrm{S}}=3.566 ; P=0.003\right)$ and no significant differences at sites not involved in antigen recognition (Table 2).

Figure 2 shows a neighbour-joining phylogenetic tree with the six Capy-DRB1 alleles and 35 DRB1 sequences representing the major $D R B 1$ allelic lineages from the domestic goat. The Capy-DRB1 sequences reported for the SI represent at least four (possibly five) major allelic lineages. These lineages are characterized by the relatively high bootstrap values (using both neighbourjoining and maximum parsimony) clustering together each Capy-DRB1 sequence with other sequences from domestic goats (Figure 2). Our phylogenetic analysis did not show support for the basal branching order among the characterized allelic lineages, which showed low bootstrap values $(<50 \%)$ in the neighbour-joining and parsimony analyses. One of the SI DRB1 alleles (CapyDRB1.4) did not show a consistent grouping with any of the characterized allelic lineages.

\section{Microsatellite analysis}

We analysed the polymorphisms of thirteen microsatellite loci in the SI. Average observed heterozygosities were 0.184 and 0.231 for $\mathrm{CPV}$ and $\mathrm{CPH}$, respectively (Table 3 ). When we made the same analysis of genetic diversity excluding monomorphic microsatellites, average observed heterozygosities raised to 0.266 (CPV) and 0.333 $(\mathrm{CPH})$. These values are remarkably low compared to those reported for microsatellites in other domestic goats and in mammal species in general. Moreover, the last representative of the CPP subspecies was homozygous for all 13 microsatellite loci analysed. A significant deficit in the frequency of heterozygotes was observed for five of the nine analysed polymorphic microsatellites, with a mean estimate of $F_{\text {IS }}=0.268 \pm 0.108(P<0.001$, Table 4$)$. 
Table 3 Mean allelic diversity $\left(N_{\mathrm{a}}\right)$ and observed $\left(H_{\mathrm{o}}\right)$ and expected $\left(H_{\mathrm{e}}\right)$ heterozygosities for 13 microsatellite loci in C. $p$. hispanica (Muela de Cortés and Beceite-Tortosa populations) and C. $p$. victoriae (Gredos and Batuecas populations)

\begin{tabular}{lcccc}
\hline Population & $\mathrm{N}$ & $\mathrm{N}_{a}$ & $\mathrm{H}_{o}$ & $\mathrm{H}_{e}^{\mathrm{a}}$ \\
\hline C. p. hispanica & 18 & $2.4 \pm 0.4$ & $0.231 \pm 0.073$ & $0.336 \pm 0.084$ \\
& & $\mathbf{3 . 0} \pm \mathbf{0 . 4}$ & $\mathbf{0 . 3 3 3} \pm \mathbf{0 . 0 8 4}$ & $\mathbf{0 . 4 8 5} \pm \mathbf{0 . 0 7 9}$ \\
Muela de Cortés & 5 & $1.7 \pm 0.2$ & $0.169 \pm 0.059$ & $0.253 \pm 0.070$ \\
& & $\mathbf{2 . 0} \pm \mathbf{0 . 2}$ & $\mathbf{0 . 2 4 4} \pm \mathbf{0 . 0 7 3}$ & $\mathbf{0 . 3 6 5} \pm \mathbf{0 . 0 7 5}$ \\
Beceite-Tortosa & 13 & $2.1 \pm 0.3$ & $0.254 \pm 0.086$ & $0.299 \pm 0.078$ \\
& & $\mathbf{2 . 6} \pm \mathbf{0 . 3}$ & $\mathbf{0 . 3 6 8} \pm \mathbf{0 . 1 0 3}$ & $\mathbf{0 . 4 3 2} \pm \mathbf{0 . 0 7 8}$ \\
C. p. victoriae & 23 & $2.0 \pm 0.3$ & $0.184 \pm 0.062$ & $0.237 \pm 0.060$ \\
Gredos & & $\mathbf{2 . 4} \pm \mathbf{0 . 2}$ & $\mathbf{0 . 2 6 6} \pm \mathbf{0 . 0 7 6}$ & $\mathbf{0 . 3 4 2} \pm \mathbf{0 . 0 5 6}$ \\
& 14 & $2.0 \pm 0.3$ & $0.192 \pm 0.065$ & $0.268 \pm 0.063$ \\
Batuecas & & $\mathbf{2 . 4} \pm \mathbf{0 . 2}$ & $\mathbf{0 . 2 7 8} \pm \mathbf{0 . 0 7 8}$ & $\mathbf{0 . 3 8 7} \pm \mathbf{0 . 0 5 4}$ \\
& 9 & $1.7 \pm 0.2$ & $0.171 \pm 0.074$ & $0.183 \pm 0.062$ \\
& & $\mathbf{2 . 0} \pm \mathbf{0 . 2}$ & $\mathbf{0 . 2 4 7} \pm \mathbf{0 . 0 9 8}$ & $\mathbf{0 . 2 6 4} \pm \mathbf{0 . 0 7 4}$ \\
\hline
\end{tabular}

${ }^{a}$ Unbiased estimate (Nei, 1978).

The number of sampled individuals is indicated as $N$. Since four of the 13 microsatellites were monomorphic, a second analysis that only included the nine polymorphic microsatellites was performed (values indicated in bold).

Table 4 Wright $F$-statistics for nine polymorphic microsatellite loci in two Spanish ibex subspecies (C. p. hispanica and C. p. victoriae)

\begin{tabular}{lccc}
\hline Locus & $\mathrm{F}_{I S}=\mathrm{f}$ & $\mathrm{F}_{I T}=\mathrm{F}$ & $\mathrm{F}_{S T}=\theta$ \\
\hline ETH 152 & $0.405^{* * *}$ & $0.548^{* * *}$ & $0.240^{* * *}$ \\
ETH 10 & -0.133 & -0.022 & $0.098^{*}$ \\
HEL 9 & $1.000^{* * *}$ & $1.000^{* * * *}$ & -0.050 \\
ETH 225 & $1.000^{* * *}$ & $1.000^{* * *}$ & -0.044 \\
CSSM 66 & $0.181^{*}$ & $0.461^{* * *}$ & $0.341^{* * *}$ \\
INRA005 & $0.308^{*}$ & $0.386^{* *}$ & $0.112^{*}$ \\
CHIRAE 54 & 0.045 & $0.368^{* * *}$ & $0.338^{* * *}$ \\
INRA 023 & 0.152 & $0.228^{* *}$ & $0.160^{* * *}$ \\
INRA 032 & -0.024 & 0.066 & $0.088^{*}$ \\
\multicolumn{2}{l}{} & & \\
Mean estimates + & $0.268(0.108)^{* * *}$ & $0.409(0.079)^{* * *}$ & $0.196(0.050)^{* * *}$
\end{tabular}

$f$, Within-population inbreeding estimate; $F$, total inbreeding estimate; $\theta$, measure of population differentiation.

+ Mean estimates obtained by jackknifing over loci. Standard deviations are indicated in parentheses.

${ }^{*} P<0.05,{ }^{* *} P<0.01,{ }^{* * *} P<0.001$, from permutation tests as implemented in the FSTAT program.

Table $5 \mathrm{~F}_{\mathrm{ST}}$ estimates (below the diagonal) as a measure of genetic distance between C. p. hispanica (CPH, Muela de Cortés and BeceiteTortosa populations) and C. p. victoriae (CPV, Gredos and Batuecas populations) and number of effective migrants per generation $\left(N_{\mathrm{e}} \mathrm{m}\right)$ (above the diagonal)

\begin{tabular}{lcccc}
\hline Population & Muela de Cortés & Beceite-Tortosa & Gredos & Batuecas \\
\hline Muela Cortés & - & 0.640 & 0.793 & 0.692 \\
Beceite-Tortosa & 0.281 & - & 0.809 & 0.602 \\
Gredos & 0.240 & 0.236 & - & 31.93 \\
Batuecas & 0.265 & 0.293 & 0.008 & - \\
\hline
\end{tabular}

The levels of genetic differentiation between CPV and $\mathrm{CPH}$ were remarkably high with a mean value of $F_{\mathrm{ST}}=0.196 \pm 0.05 \quad(P<0.001$, Table 4$)$. Moreover, when we made the pairwise comparison of four SI populations from Gredos (CPV, $N=14)$, Batuecas $(\mathrm{CPV}, N=9)$, Muela de Cortés $(\mathrm{CPH}, \mathrm{N}=5)$, and Beceite-Tortosa $(\mathrm{CPH}$,

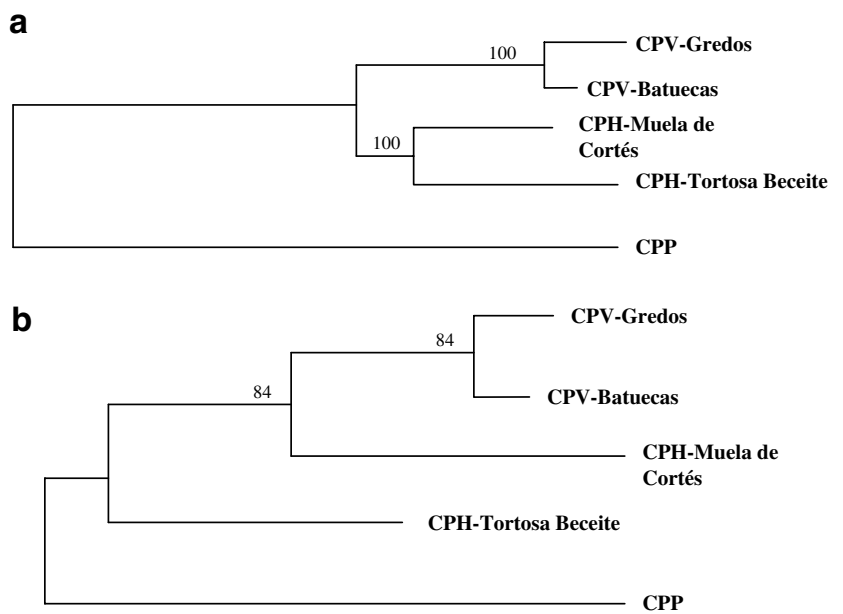

Figure 3 Dendrogram showing the genetic relationships among the C. p. hispanica (Muela de Cortés and Beceite-Tortosa populations), C. $p$. victoriae (Gredos and Batuecas populations) and the last representative of the $C$. $p$. pyrenaica subspecies, according to the polymorphism of (a) the Capy-DRB1 gene and (b) a panel of 13 microsatellites. The phylogenetic trees were constructed by using the neighbour joining method and the $D_{\mathrm{A}}$ genetic distances. The consistency of the dendrogram was evaluated by bootstrap resampling of loci (1000 replicates).

$N=13)$ the high $F_{\mathrm{ST}}$ values were indicative of a high degree of population structure (Table 5). The only exception to this general trend was represented by the pairwise comparison of the Gredos vs Batuecas populations, which displayed an $F_{\mathrm{ST}}$ value of 0.008 and an $N_{\mathrm{e}} \mathrm{m}$ estimate of approximately 31.93 (Table 5). This result is consistent with the neighbour-joining phylogenetic analysis of the SI subspecies and populations based on the polymorphisms of the Capy-DRB1 gene and 13 microsatellites, clustering the Gredos and Batuecas populations (Figure 3).

\section{Discussion}

The genetic analysis of the MHC DRB1 gene reported in this study demonstrates that the SI, a wild goat species from the Iberian Peninsula, consistently showed low levels of genetic diversity at this locus with only six Capy-DRB1 alleles. Observed and expected heterozygosities were comparable to those reported in other bottlenecked wild species such as bontebok (Damaliscus pygargus pygargus, $N=44$ individuals, $H_{\mathrm{o}}=0.51$, $H_{\mathrm{e}}=0.71$ ) and the Norwegian and Swedish moose (Alces alces, $N=218$ individuals, $H_{\mathrm{e}}=0.76-0.79$ ) (Mikko et al, 1999; Van der Walt et al, 2001) (Table 1). With regard to allelic diversity, the number of Capy-DRB1 alleles identified by PCR-RFLP analysis and direct sequencing was consistently lower in CPV and CPH $(N=40$ individuals, four alleles) than in reindeer (Rangifer tarandus, $N=60$ individuals, 11 alleles), North American bison (Bison bison, $N=20$ individuals, nine alleles) and bontebok $(N=44$ individuals, six alleles), which are wild ruminant species that have passed through known demographic bottlenecks and consequently have restricted diversity at their MHC loci (Mikko et al, 1999; Van der Walt et al, 2001). 
As MHC class II genes are fundamental for the immune response of organisms against pathogenic and parasite infections, the presence of specific MHC allele variants in the SI may be the result of natural selection favouring host resistance to infectious diseases. DNA sequence analyses of the six DRB1 alleles in the SI revealed a significantly higher rate of nonsynonymous $v s$ synonymous substitutions in the PBR region of the DR $\beta$ protein, which is responsible for the binding and presentation of extracellular peptides to T cells (Table 2). A ratio of $d_{\mathrm{N}} / d_{\mathrm{S}}$ greater than one suggests that variation at the antigen-binding sites is under positive selection, probably for the recognition of a wide range of infectious agents (Hughes and Yeager, 1998). Our phylogenetic analyses showed that the Capy-DRB1 sequences from the SI were widely distributed throughout the DRB1 gene tree, clustering consistently with sequences from the domestic goat, rather than grouping together with each other. This suggests that the DRB1 alleles currently present in the SI have originated prior to the divergence of this species and the domestic goat about 1-6 MYR ago (Manceau, 1997).

We believe that the reduced Capy-DRB1 allelic repertoire we have observed is the direct result of the recent history of population bottlenecks and marked demographic decline that the SI experienced during the last two centuries (Pérez et al, 2002). Although current estimates of population sizes for the extant subspecies indicate the existence of several nuclei with thousands of individuals (Beceite-Tortosa, Muela de Cortés, Gredos, Cazorla, Sierra Nevada and others), historical records indicate that most populations have passed through demographic bottlenecks of less than 100 individuals (Manceau, 1997, Pérez et al, 2002).

A genetic survey of 13 microsatellite loci provided independent evidence demonstrating that low genetic variation is not only circumscribed to the MHC. Contrary to reported microsatellite data from domestic goat breeds, which displayed 5.6-6.8 alleles per locus and mean expected heterozygosities of 0.57-0.79 (Luikart et al, 1999; Saitbekova et al, 1999; Li et al, 2002), the SI subspecies showed considerably low levels of both heterozygosity and allelic diversity (Table 3), suggesting that the demographic decline of the SI resulted in an overall reduction of genetic diversity at the genome level. Observed $\left(H_{\mathrm{o}}=0.266-0.333\right)$ and expected $\left(H_{\mathrm{e}}=0.342-\right.$ $0.485)$ heterozygosities become higher if monomorphic microsatellites are excluded from the analysis of genetic diversity, but they are still remarkably small. These values are very similar to the ones reported for other endangered species with a similar demographic history of genetic bottlenecks, such as the Alpine ibex (Capra ibex, Maudet et al, 2002) and the fallow deer (Poetsch et al, 2001). Allelic diversity was also very limited, with four microsatellites that were monomorphic in both subspecies. Moreover, four $(\mathrm{CPH})$ and six $(\mathrm{CPV})$ of the remaining polymorphic microsatellites were biallelic (data not shown). The mean $F_{\mathrm{ST}}$ value for the 13 microsatellite markers was 0.196, indicating a significant degree of genetic differentiation between CPV and $\mathrm{CPH}$ (Table 4). The calculation of the $F_{\mathrm{ST}}$ values and the number of effective migrants per generation $\left(N_{\mathrm{e}} \mathrm{m}\right)$ in four CPV and CPH populations made evident the existence of population subdivision, although these data should be interpreted with caution due to the small sample size per population (Table 5). Interestingly, the occurrence of significant gene flow between the Gredos and Batuecas populations was detected (Table 5). This result is consistent with the geographical proximity of these populations (Figure 1) and the phylogenetic analysis of the SI populations based on the polymorphisms of the Capy-DRB1 gene and 13 microsatellites (Figure 3).

Results from this study emphasize the importance of both natural selection and the demographic history of populations in determining patterns of genetic variation at MHC loci. Sequence analysis of the SI mitochondrial control and cytochrome $b$ gene regions by Manceau et $a$ l (1999) demonstrated that the level of divergence between CPP and the other two extant SI subspecies was almost as high as the divergence between the SI and the Alpine ibex. We hypothesize that the recent extinction of the CPP subspecies might have involved a marked reduction in the allelic pool of the Capy-DRB1 and other MHC genes. Moreover, it may have led to the extinction of certain MHC alleles that were specific to this subspecies. Since reduced MHC variation has been previously associated with higher susceptibility to infectious diseases in some cases (Potts et al, 1994; Paterson et al, 1998; Hedrick and Kim, 2000), we may expect consequent effects on fitness, particularly if populations become exposed to disease epidemics. Genetic analyses of Capy$D R B 1$ sequences from museum specimens or samples from preserved bones would be necessary to directly assess historical levels of MHC variation in the SI and, thus, evaluate the relative role that demographic changes may have played in determining existing levels of genetic diversity at the MHC.

\section{Acknowledgements}

We thank Professor Ron Woodruff for suggestions on earlier versions of this manuscript. This research was funded by the Department of Agriculture and Environment of the Diputación General de Aragón (Spain) and the Life Program of the European Community.

GenBank accession numbers of the Spanish ibex DRB1 DNA sequences reported in this study: AF461692, AF461693, AF461694, AF461695, AF461696, AY351788

\section{References}

Amills M, Francino O, Sànchez A (1996a). A PCR-RFLP typing method for the caprine Mhc class II DRB gene. Vet Immunol Immunopathol 55: 255-260.

Amills M, Francino O, Sànchez A (1996b). A caprine dinucleotide repeat: microsatellite CHI AE54. Anim Genet 27: 435-436.

Barendse W, Armitage SM, Kossarek LM, Shalom A, Kirkpatrick BW, Ryan AM et al. (1994). A genetic linkage map of the bovine genome. Nat Genet 6: 227-235.

Brezinsky L, Kemp SJ, Teale AJ (1993). ILSTS005 - a polymorphic bovine microsatellite. Anim Genet 24: 73.

Brown JH, Jardetzky TS, Gorga JC, Stern LJ, Urban RG, Strominger JL et al (1993). Three-dimensional structure of the human class II histocompatibility antigen HLA-DR1. Nature 364: 33-39.

Cabrera A (1911). The subspecies of the Spanish ibex. Proc Zool Soc London LXVI: 963-977.

Crampe JP (1991). Le bouquetin ibérique-éléments pour une réintroduction au versant nord des Pyrénées occidentales. 
Documents scientifiques du Parc National des Pyrénées, Parc National des Pyrénées.

Ellegren H, Hartman G, Johansson M, Andersson L (1993). Major histocompatibility complex monomorphism and low levels of DNA fingerprinting variability in a reintroduced and rapidly expanding population of beavers. Proc Natl Acad Sci USA 90: 8150-8153.

Goudet J (2000). FSTAT Ver. 2.9.1. Computer package for PCs. Institute of Ecology, Biology Building, UNIL, CH-1015 Lausanne, Switzerland.

Hedrick PW, Kim TJ (2000). Genetics of complex polymorphisms: parasites and the maintenance of the major histocompatibility complex variation. In: Singh RS, Krinbas CB (eds) Evolutionary Genetics: From Molecules to Morphology. Cambridge University Press: Cambridge, UK, pp 204-234.

Hughes AL, Hughes MK, Howell CY, Nei M (1994). Natural selection at the class II major histocompatibility complex loci of mammals. Philos Trans R Soc Lond B Biol Sci 346: 359-366.

Hughes AL, Yeager M (1998). Natural selection at major histocompatibility complex loci of vertebrates. Annu Rev Genet 32: 415-435.

Jiménez N, Folch J, Fernández-Arias A, Guiral J, Sànchez A (1999). Estudio genético mediante marcadores microsatélites de las poblaciones de cabra montés. Inf Técn Agr 20: 300-302.

Jukes TH, Cantor CR (1969). Evolution of protein molecules. In: Munro HN (ed) Mammalian Protein Metabolism. Academic Press: New York, pp 21-132.

Kaukinen J, Varvio SL (1993). Eight polymorphic bovine microsatellites. Anim Genet 24: 148.

Kumar S, Tamura K, Nei M (1993). MEGA: Molecular Evolutionary Genetic Analysis version 1.01 The Pennsylvania State University: University Park, PA.

Li MH, Zhao SH, Bian C, Wang HS, Wei H, Liu B et al (2002). Genetic relationships among twelve Chinese indigenous goat populations based on microsatellite analysis. Genet Sel Evol 34: 729-744.

Luikart G, Biju-Duval MP, Ertugrul O, Zagdsuren Y, Maudet C, Taberlet P (1999). Power of 22 microsatellite markers in fluorescent multiplexes for parentage testing in goats (Capra hircus). Anim Genet 30: 431-438.

Manceau V (1997). Polymorphisme des séquences d'ADN mitochondrial dans le genre Capra. Application à la conservation du bouquetin des Pyrénées (C. pyrenaica pyrenaica). Doctoral Thesis, University Joseph Fourier.

Manceau V, Crampe JP, Boursot P, Taberlet P (1999). Identification of evolutionary significant units in the Spanish wild goat, Capra Pyrenaica (Mammalia, Artiodactyla). Anim Conserv 2: 33-39.

Maudet C, Miller C, Bassano B, Breitenmoser-Wursten C, Gauthier D, Obexer-Ruff G et al (2002). Microsatellite DNA and recent statistical methods in wildlife conservation management: applications in Alpine ibex [Capra ibex(ibex)]. Mol Ecol 11: 421-436.

Mikko S, Røed K, Schmutz S, Andersson L (1999). Monomorphism and polymorphism at Mhc DRB loci in domestic and wild ruminants. Immunol Rev 167: 169-178.

Nei M (1978). Estimation of average heterozygosity and genetic distance from a small number of individuals. Genetics 89: 583-590.

Nei M, Gojobori T (1986). Simple methods for estimating the numbers of synonymous and nonsynonymous nucleotide substitutions. Mol Biol Evol 3: 418-426.

Nei M, Kumar S (2000). Molecular Evolution and Phylogenetics. Oxford University Press: New York.

Nei M, Tajima F, Tateno T (1983). Accuracy of estimated phylogenetic trees from molecular data. J Mol Evol 19: 153-170.

O'Brien SJ, Evermann JF (1988). Interactive influence of infectious disease and genetic diversity in natural populations. Trends Ecol Evol 3: 254-259.

O'Brien SJ, Wildt DE, Bush M, Caro TM, FitzGibbon C, Aggundey I et al (1987). East African cheetahs: evidence for two population bottlenecks? Proc Natl Acad Sci USA 84: 508-511.

Ota T (1993). DISPAN: Genetic Distance and Phylogenetic Analysis. Pennsylvania State University: University Park, PA.
Paterson S, Wilson K, Pemberton JM (1998). Major histocompatibility complex variation associated with juvenile survival and parasite resistance in a large unmanaged ungulate population. Proc Natl Acad Sci USA 95: 3714-3719.

Pérez JM, Granados JE, Soriguer RC, Fandos P, Márquez FJ, Crampe JP (2002). Distribution, status and conservation problems of the Spanish ibex, Capra pyrenaica (Mammalia: Artiodactyla). Mammal Rev 32: 26-39.

Poetsch M, Seefeldt S, Maschke M, Lignitz E (2001). Analysis of microsatellite polymorphism in red deer, roe deer, and fallow deer - possible employment in forensic applications. Forensic Sci Int 116: 1-8.

Potts WK, Manning CJ, Wakeland EK (1994). The role of infectious disease, inbreeding and mating preferences in maintaining MHC genetic diversity: an experimental test. Philos Trans $R$ Soc Lond B Biol Sci 346: 369-378.

Raymond M, Rousset F (1995). GENEPOP (Version 3.3): population genetics software for exact test and ecumenicism. J Hered 86: 248-249.

Saitbekova N, Gaillard C, Obexer-Ruff G, Dolf G (1999). Genetic diversity in Swiss goat breeds based on microsatellite analysis. Anim Genet 30: 36-41.

Saitou N, Nei M (1987). The neighbor-joining method: a new method for reconstructing phylogenetic trees. Mol Biol Evol 4: 406-425.

Sambrook J, Fritsch EF, Maniatis T (1989). Molecular Cloning: A Laboratory Manual 2nd edn Cold Spring Harbor Laboratory Press: New York.

Schneider S, Roessli D, Excoffier L (2000). Arlequin, Ver. 2.000 A software for population genetic data analysis. University of Geneva, Geneva, Switzerland.

Slatkin M (1993). Isolation by distance in equilibrium and nonequilibrium populations. Evolution 47: 264-279.

Steffen P, Eggen A, Dietz AB, Womack JE, Stranzinger G, Fries R (1993). Isolation and mapping of polymorphic microsatellites in cattle. Anim Genet 24: 121-124.

Swofford DL, Selander RB (1999). BIOSYS-2: A computer program for the analysis of allelic variation in population genetics and biochemical systematics (Release 2.0). University of Illinois: Urbana, Champaign, IL.

Takezaki N, Nei M (1996). Genetic distance and reconstruction of phylogenetic trees from microsatellite DNA. Genetics 144: 389-399.

Thompson JD, Gibson TJ, Plewniak F, Jeanmougin F, Higgins DG (1997). The CLUSTAL X window interface: flexible strategies for multiple sequence alignment aided by quality analysis tools. Nucleic Acids Res 25: 4876-4882.

Toldo SS, Fries R, Steffen P, Neibergs HL, Barendse W, Womack JE et al (1993). Physically mapped, cosmid-derived microsatellite markers as anchor loci on bovine chromosomes. Mamm Genome 4: 720-727.

Trowsdale J (1993). Genomic structure and function in the MHC. Trends Genet 9: 117-122.

Vaiman D, Mercier D, Moazami-Goudarzi K, Eggen A, Leveziel H (1994). A set of 99 cattle microsatellites: characterisation, synteny mapping and polymorphism. Mamm Genome 5: 288-297.

Van der Walt JM, Nel LH, Hoelzel AR (2001). Characterization of major histocompatibility complex DRB diversity in the endemic South African antelope Damaliscus pygargus: a comparison in two subspecies with different demographic histories. Mol Ecol 10: 1679-1688.

Watkins DI, Garber TL, Chen ZW, Toukatly G, Hughes AL, Letvin NL (1991). Unusually limited nucleotide sequence variation of the expressed major histocompatibility complex class I genes of a New World primate species (Saguinus oedipus). Immunogenetics 33: 79-89.

Weir BS, Cockerham CC (1984). Estimating F-statistics for the analysis of population structure. Evolution 38: 1358-1370.

Yuhki N, O'Brien SJ (1990). DNA variation of the mammalian major histocompatibility complex reflects genomic diversity and population history. Proc Natl Acad Sci USA 87: 836-840. 